\title{
Effects of supplemental $\beta$-carotene on mucosal $\lg A$ induction in the jejunum and ileum of mice after weaning
}

\author{
Keita Nishida, Miki Sugimoto, Shuntaro Ikeda and Shinichi Kume* \\ Graduate School of Agriculture, Kyoto University, Kitashirakawa Oiwake-cho, Sakyo-ku, Kyoto 606-8502, Japan
}

(Submitted 5 February 2013 - Final revision received 4 June 2013 - Accepted 7 June 2013 - First published online 8 July 2013)

\section{Abstract}

An adequate immune system is required to prevent diarrhoea in neonates, and IgA provides protection against microbial antigens on mucosal surfaces. Although $\beta$-carotene supplementation has been expected to enhance the retinoic acid (RA)-mediated immune response in neonates, the exact mechanism of the enhancement of mucosal IgA production in the small intestine by $\beta$-carotene is still unclear. In the present study, we investigated the effect of supplemental $\beta$-carotene on the concentrations of IgA, the numbers of IgA antibody-secreting cells (ASC) and the mRNA expressions of IgA C-region, CCL25, retinoid X receptor $(R X R) \alpha$, retinoic acid receptor $(R A R) \alpha$ and $R A R \gamma$ in the jejunum and ileum of weanling mice. Weanling mice were fed rodent feed or $50 \mathrm{mg} / \mathrm{kg} \beta$-carotene-supplemented rodent feed for 7,14 or $21 \mathrm{~d}$. The concentrations of IgA and the numbers of IgA ASC in the jejunum and ileum of mice increased markedly with age, and supplemental $\beta$-carotene increased the concentrations of IgA, the numbers of IgA ASC and the mRNA expressions of IgA C-region, CCL25 and $R A R \gamma$ in the jejunum after 14 and $21 \mathrm{~d}$ of treatment. Supplemental $\beta$-carotene increased the numbers of IgA ASC in the ileum after 14 and $21 \mathrm{~d}$ of treatment, but the concentrations of IgA in the ileum were not affected by $\beta$-carotene supplementation. The mRNA expressions of $R X R \alpha$ and $R A R \alpha$ in the jejunum and those of $R X R \alpha$ and $R A R \gamma$ in the ileum after $21 \mathrm{~d}$ of treatment were enhanced by $\beta$-carotene supplementation. These results indicate that $\beta$-carotene supplementation in weanling mice is effective to enhance mucosal IgA induction in the jejunum or ileum and that the effects are mainly due to the RA-mediated immune response.

Key words: Supplemental $\beta$-carotene: Jejunum: Ileum: IgA induction: Weanling mice

Mortality and morbidity of neonates continue to be major problems in humans and animals, and their most common cause is diarrhoea. Optimal neonatal health depends on many factors related to management and nutrition, but improvement of the immune system is required to prevent diarrhoea. IgA is the most abundant Ig isotype in mucosal secretions and provides protection against microbial antigens on mucosal surfaces ${ }^{(1-3)}$, and IgA antibodies produced by IgA antibody-secreting cells (ASC) in the intestines and mammary glands are mainly secreted as dimers ${ }^{(1,4)}$. Supplemental vitamin $A$ and $\beta$-carotene enhance the immune response of neonates ${ }^{(5-9)}$, and supplementation of vitamin A decreases the incidence of diarrhoea and mortality in malnourished children $^{(10,11)}$. In previous studies ${ }^{(12,13)}$, it has been observed that $\beta$-carotene supplementation in maternal mice during pregnancy and lactation increases the numbers of IgA ASC in the mammary glands and ileum of lactating mice and enhances IgA transfer from maternal milk to neonatal mice. However, very few IgA ASC are detected in the jejunum and ileum of neonatal mice at $14 \mathrm{~d}$ of age and most IgA in neonatal mice may be derived from milk $\operatorname{IgA}^{(12)}$. Decreased intestinal secretions of IgA in mice can be found at weaning, and the concentrations of IgA rise rapidly after weaning and reach a maximum level at 10 weeks of age ${ }^{(14)}$. Thus, the enhancement of mucosal IgA induction is important for maintaining a normal immune system in neonates.

Gut-associated lymphoid tissue is the largest immunological tissue in the body. Peyer's patches are the main site for the generation of $\mathrm{IgA}^{+} \mathrm{B}$ cells, and plasmablasts differentiating from $\mathrm{IgA}^{+} \mathrm{B}$ cells preferentially home in on the gut lamina propria through the thoracic duct and blood by the expression of homing ligands and receptors ${ }^{(1-3)}$. Chemokines are transmembrane proteins that play important roles in innate and acquired immunity ${ }^{(15-17)}$, and chemokine ligand CCL25 is selectively expressed in the small intestine and its receptor CCR9 is expressed by almost all $\mathrm{T}$ cells in the small intestine and a fraction of $\operatorname{IgA~ASC}{ }^{(18)}$. The interplay of CCL25 and CCR9 is likely to have a significant role in the recruitment of developing thymocytes ${ }^{(19)}$, and the selective expression of CCL25 in the small bowel underlies the homing of $\mathrm{CCR}^{+}$intestinal memory $\mathrm{T}$ cells to the small bowel $^{(20)}$.

Abbreviations: ASC, antibody-secreting cells; pIgR, polymeric Ig receptor; RA, retinoic acid; RAR, retinoic acid receptor; RXR, retinoid X receptor.

*Corresponding author: S. Kume, fax +81 75753 6345, email kume@kais.kyoto-u.ac.jp 
The vitamin A metabolite all-trans retinoic acid (RA) plays important roles in gut immunity and RA is necessary for the imprinting of gut-homing specificity on T cells and the induction of gut-homing receptors on B cells and IgA ASC ${ }^{(16,17)}$. Several effects of carotenoids are thought to be mediated by their metabolism to vitamin A and subsequent mediation of retinoic acid receptor (RAR) and retinoid $\mathrm{X}$ receptor (RXR) response pathways ${ }^{(7)}$. RA is a highly potent activator of RAR and RXR and influences the transcription of various retinoid response genes by the activation of these receptors ${ }^{(7,21,22)}$. RA regulates the apoptosis of $\mathrm{T}$ lymphocytes through interplay between RAR and RXR, but RAR $\alpha$ and RAR $\gamma$ induce opposite effects during thymic selection ${ }^{(23)}$. The expressions of RAR and RXR isotypes vary greatly in different tissues, but human lymphocytes express $\operatorname{RXR} \alpha, \operatorname{RAR} \alpha$ and $\operatorname{RAR} \gamma^{(3,24)}$. Supplemental $\beta$-carotene increases the mRNA expression of $\operatorname{Ig} A$ C-region and the numbers of IgA ASC in the ileum of lactating mice, and these effects may be mainly due to the RA-mediated immune response ${ }^{(12)}$. However, the exact mechanism of the enhancement of mucosal IgA induction in the intestines of neonates by $\beta$-carotene is still unclear, although $\beta$-carotene supplementation has been expected to enhance RA-mediated immune response in neonates ${ }^{(12,13)}$.

In the present study, we investigated the effect of supplemental $\beta$-carotene on the concentrations of IgA, the numbers of IgA ASC and the mRNA expressions of $\operatorname{Ig} A$ C-region, $C C L 25, R X R \alpha, R A R \alpha$ and $R A R \gamma$ in the jejunum and ileum of weanling mice. The present study demonstrates that $\beta$-carotene supplementation in weanling mice is effective to enhance mucosal IgA induction in the jejunum or ileum, because it increases the concentrations of IgA, the numbers of IgA ASC and the mRNA expression of $\operatorname{Ig} A$ C-region in the jejunum and also the numbers of IgA ASC in the ileum. These effects may be mainly due to the RA-mediated immune response, owing to the increased mRNA expressions of CCL25, RXR $\alpha, R A R \alpha$ and $R A R \gamma$ in the jejunum and of $R X R \alpha$ and $R A R \gamma$ in the ileum.

\section{Materials and methods}

\section{Animals and diets}

Male weanling ICR mice aged $21 \mathrm{~d}$ ( $n$ 44) were purchased from Clea Japan (Tokyo, Japan). They were housed in individual polycarbonate cages and maintained in an air-conditioned room $\left(24 \pm 2^{\circ} \mathrm{C}\right)$ under controlled lighting conditions $(14 \mathrm{~h}$ light-10 h dark cycle). They received humane care in accordance with the 'Regulation on Animal Experimentation at Kyoto University' (Animal Research Committee, Kyoto University, revised 2007).

Weanling mice were randomly allocated to the control or $\beta$-carotene group at $21 \mathrm{~d}$ of age. Mice in the control group were fed rodent feed (Oriental Yeast) for 7 ( $n$ 8), 14 ( $n$ 8) or $21(n 6) \mathrm{d}$, and those in the $\beta$-carotene group were fed $50 \mathrm{mg} / \mathrm{kg} \beta$-carotene-supplemented rodent feed for 7 ( $n$ 8), $14(n 8)$ or $21(n 6) \mathrm{d}$. The rodent feed contained a vitamin mix, and vitamin A concentration was $385 \mu \mathrm{g}$ retinol activity equivalent $/ 100 \mathrm{~g}$, but $\beta$-carotene was not supplemented to the control group. For the $\beta$-carotene group, $\beta$-carotene was mixed with the rodent feed at $50 \mathrm{mg} / \mathrm{kg}$. All mice were given free access to water and feed. Body weights and feed intake of mice were measured at 07.00 hours every day.

\section{Sample collection}

Blood samples from eight mice in the control and $\beta$-carotene groups after 7 and $14 \mathrm{~d}$ of treatment and six mice in the control and $\beta$-carotene groups after $21 \mathrm{~d}$ of treatment were obtained by cardiac puncture under anaesthesia with Avertin (2,2,2-tribromoethanol; Sigma-Aldrich Chemical), and then jejunum, ileum and rectal faeces were removed after euthanasia by cervical dislocation. The samples of jejunum and ileum were immediately frozen in dry ice-cooled isopentane (2-methylbutane; Wako Pure Chemicals) for immunohistochemical analysis or frozen in liquid $\mathrm{N}_{2}$ and stored at $-80^{\circ} \mathrm{C}$ for IgA immunoassay and semi-quantitative RT-PCR. Blood samples were left to stand at room temperature for $1 \mathrm{~h}$ and then centrifuged at $3000 \mathrm{rpm}$ for $15 \mathrm{~min}$. The samples of serum and rectal faeces were stored at $-20^{\circ} \mathrm{C}$ until IgA analysis.

\section{IgA immunoassay and immunohistochemical analysis}

IgA immunoassay of serum, jejunum, ileum and faeces and immunohistochemical analysis of jejunum and ileum were carried out as described previously ${ }^{(12)}$. IgA concentrations were measured using the Mouse IgA ELISA Quantitation Kit (Bethyl Laboratories) and the ELISA Starter Accessory Package (Bethyl Laboratories) according to the manufacturer's instructions. The sections obtained from the immunohistochemical analysis were examined under an epifluorescence microscope (BX50; Olympus), and the resulting images were analysed using Image $\mathrm{J}$ software (National Institutes of Health). IgA-positive cells in the jejunum and ileum were counted in the lamina propria of villi in eight randomised villi from each mouse and reported as IgA ASC/unit area of the lamina propria of villi (unit $=10000 \mu \mathrm{m}^{2}$ ).

\section{Semi-quantitative RT-PCR}

The mRNA expressions of IgA C-region, CCL25, RXR $\alpha, R A R \alpha$ and $R A R \gamma$ in the jejunum and ileum were examined by semiquantitative RT-PCR as described previously ${ }^{(12)}$. The relative abundance of a specific mRNA was normalised by the abundance of glyceraldehyde-3-phosphate dehydrogenase $(G A P D H)$ mRNA. The primer pairs and PCR conditions used for $I g A$ C-region and $G A P D H$ were the same as those used in the previous study ${ }^{(12)}$. The primer pairs for CCL25 were as follows: forward: 5'-CCTTCAGGTATCTGGAGAGGAGATC-3' and reverse: 5'-CAAGATTCTTATCGCCCTCTTCA- $3^{\prime}$. The PCR was carried out as follows: after $95^{\circ} \mathrm{C}$ for $7 \mathrm{~min}$ to denature DNA, PCR was conducted for thirty-three cycles at $94^{\circ} \mathrm{C}$ for $1 \mathrm{~min}, 55^{\circ} \mathrm{C}$ for $1 \mathrm{~min}$ and $72^{\circ} \mathrm{C}$ for $1 \mathrm{~min}$, and then for one cycle at $72^{\circ} \mathrm{C}$ for $7 \mathrm{~min}$. The primer pairs for $R X R \alpha$ were as follows: forward: $5^{\prime}$-GAGCAGCACTGAGGATATCAAGC- $3^{\prime}$ and reverse: $5^{\prime}$-GGTCAGGTCTTTGCGTACTGTCC- $3^{\prime}$. The PCR was carried out as follows: after $95^{\circ} \mathrm{C}$ for $7 \mathrm{~min}$ to denature DNA, PCR was conducted for thirty-five cycles at $94^{\circ} \mathrm{C}$ for $1 \mathrm{~min}$, 

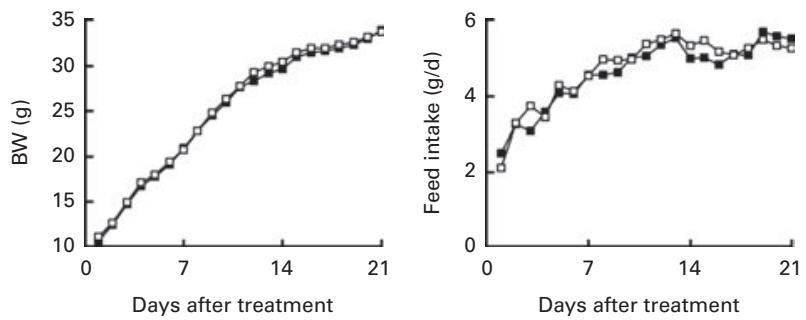

Fig. 1. Body weights (BW) and feed intake of the control $(\boldsymbol{\square} ; n$ ) ) and $\beta$-carotene $(\square ; n 6)$ groups during $21 \mathrm{~d}$ of treatment.

$57^{\circ} \mathrm{C}$ for $1 \mathrm{~min}$ and $72^{\circ} \mathrm{C}$ for $1 \mathrm{~min}$, and then for one cycle at $72^{\circ} \mathrm{C}$ for $7 \mathrm{~min}$. The primer pairs for $R A R \alpha$ were as follows: forward: 5'-AGCACCAGCTTCCAGTCAGT-3' and reverse: $5^{\prime}$-AGTGGTAGCCGGATGATTTG-3'. The PCR was carried out as follows: after $95^{\circ} \mathrm{C}$ for $7 \mathrm{~min}$ to denature DNA, PCR was conducted for thirty-seven cycles at $94^{\circ} \mathrm{C}$ for $1 \mathrm{~min}, 53^{\circ} \mathrm{C}$ for $1 \mathrm{~min}$ and $72^{\circ} \mathrm{C}$ for $1 \mathrm{~min}$, and then for one cycle at $72^{\circ} \mathrm{C}$ for $7 \mathrm{~min}$. The primer pairs for $R A R \gamma$ were as follows: forward: $5^{\prime}$-GGGCAAGTACACCACGAACT- $3^{\prime}$ and reverse: $5^{\prime}$ - ATCCGCAGCATTAGGATGTC- $3^{\prime}$. The PCR was carried out as follows: after $95^{\circ} \mathrm{C}$ for 7 min to denature DNA, PCR was conducted for thirty-seven cycles at $94^{\circ} \mathrm{C}$ for $1 \mathrm{~min}, 53^{\circ} \mathrm{C}$ for $1 \mathrm{~min}$ and $72^{\circ} \mathrm{C}$ for $1 \mathrm{~min}$, and then for one cycle at $72^{\circ} \mathrm{C}$ for $7 \mathrm{~min}$.

\section{Statistical analysis}

Data are expressed as mean values with their standard errors. Data of body weights and feed intake were analysed by least-squares ANOVA using the general linear model procedure of Statistical Analysis Systems (SAS Institute) ${ }^{(25)}$. The model was as follows:

$$
Y_{i j k}=\mu+T_{i}+M_{(i) j}+D_{k}+T D_{i k}+e_{i j k},
$$

where $\mu$ is the overall mean, $T_{i}$ is the effect of treatment, $M_{(i) j}$ is the random variable of mice nested in treatment, $D_{k}$ is the effect of sampling day, $T D_{i k}$ is the interactions and $e_{\mathrm{ijk}}$ is the residuals. The general linear model procedure of Statistical Analysis Systems ${ }^{(25)}$ was used to analyse the effects of treatment or time on some variables in mice. Significance was declared at $P<0 \cdot 05$.

\section{Results}

\section{IgA concentrations in serum and tissues}

Body-weight gains and feed intake of mice during $21 \mathrm{~d}$ of treatment as well as those of mice during 7 and $14 \mathrm{~d}$ of treatment (data not shown) were similar between the groups (Fig. 1). IgA concentrations in the jejunum of the $\beta$-carotene group were significantly higher than those of the control group after $14(P<0.01)$ and $21(P<0.05) \mathrm{d}$ of treatment, but IgA concentrations in the serum, ileum and faeces of mice after 7, 14 and $21 \mathrm{~d}$ of treatment were not affected by the treatment (Fig. 2). Compared with the IgA concentrations of mice after $7 \mathrm{~d}$ of treatment, those in the serum $(P<0.001)$ and faeces $(P<0.01)$ increased after 14 and $21 \mathrm{~d}$ of treatment. IgA concentrations in the jejunum and ileum increased $(P<0 \cdot 001)$ with age.
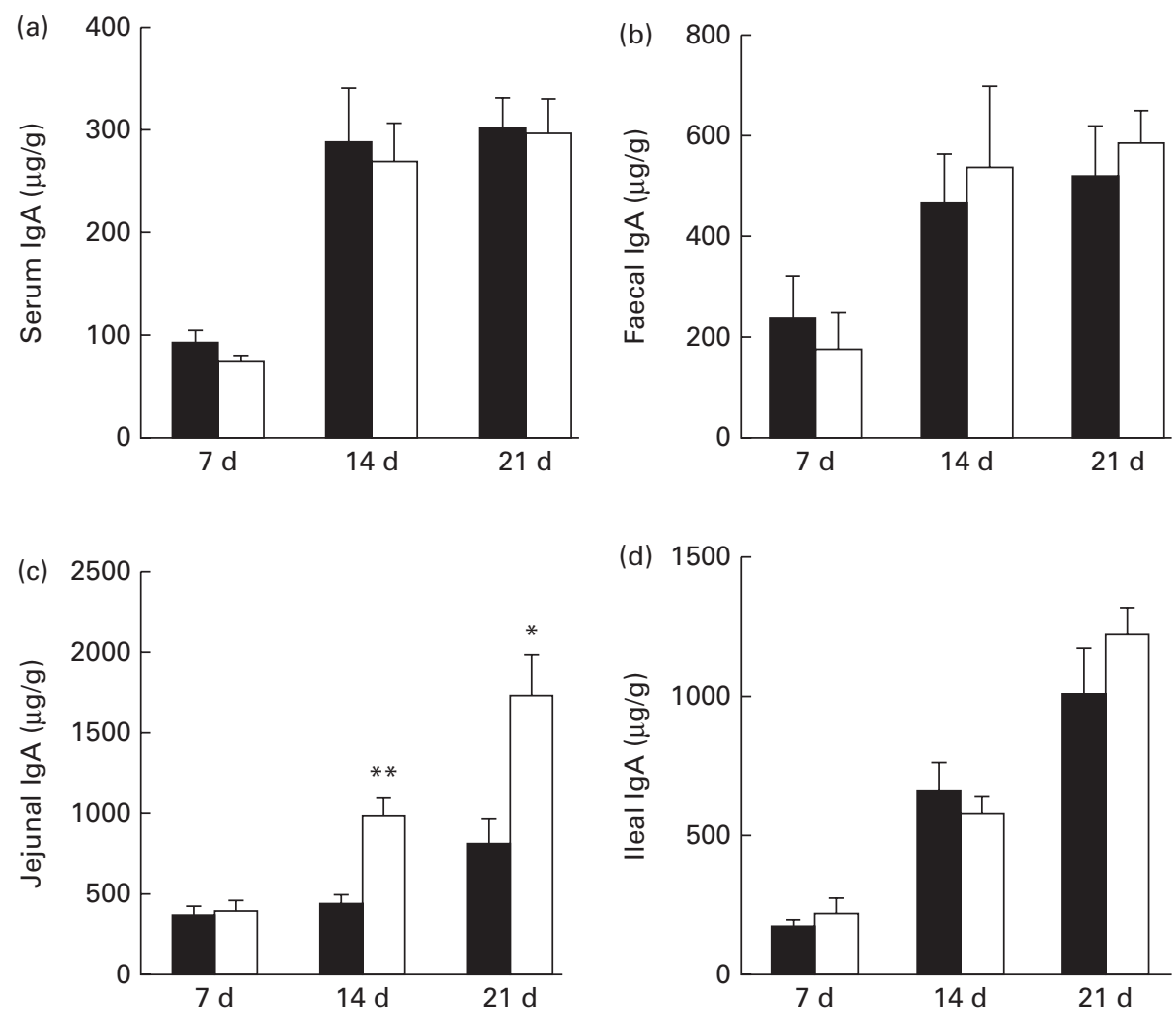

Fig. 2. IgA concentrations $(\mu \mathrm{g} / \mathrm{g})$ in the (a) serum, (b) faeces, (c) jejunum and (d) ileum of the control group ( $\square$ ) after 7 ( $n$ 8), $14(n 8)$ and $21(n 6) \mathrm{d}$ of treatment and of the $\beta$-carotene group $(\square)$ after $7(n 8), 14(n 8)$ and $21(n 6) \mathrm{d}$ of treatment. Values are means, with their standard errors represented by vertical bars. Mean value was significantly different from that of the control group: ${ }^{*} P<0.05$, ${ }^{\star *} P<0.01$. 

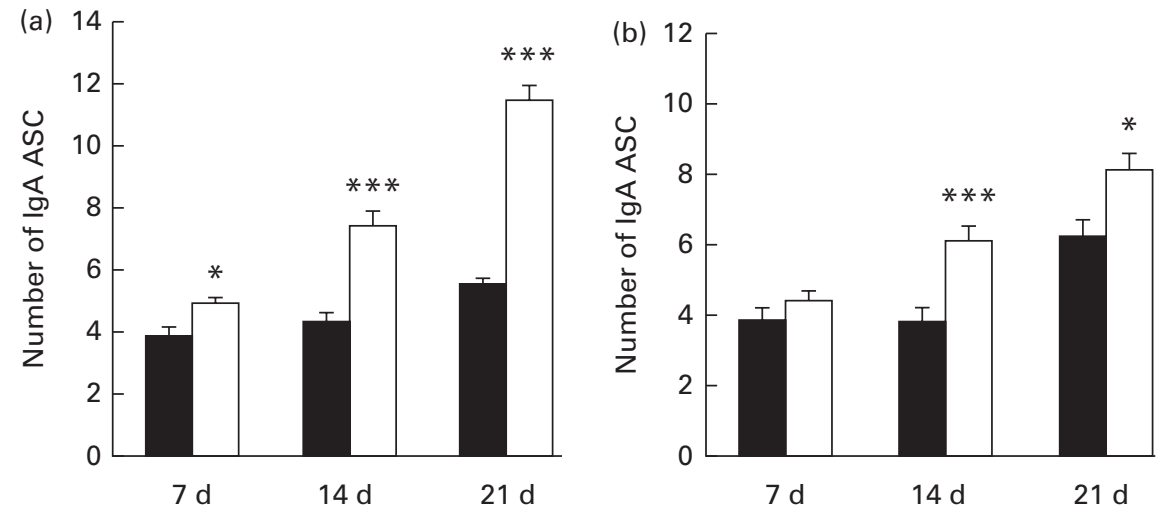

Fig. 3. Numbers of IgA antibody-secreting cells (ASC) in the (a) jejunum and (b) ileum of the control group (অ) after $7(n 8), 14(n 8)$ and 21 ( $n$ 6) d of treatment and of the $\beta$-carotene group $(\square)$ after $7(n 8), 14(n 8)$ and $21(n 6) d$ of treatment. Values are means, with their standard errors represented by vertical bars. The numbers of IgA ASC in the jejunum and ileum were counted in the lamina propria of villi in eight randomised villi from each mouse. Mean value was significantly different from that of the control group: ${ }^{*} P<0.05,{ }^{\star \star *} P<0.001$.

\section{IgA antibody-secreting cells in tissues}

The numbers of IgA ASC in the jejunum of the $\beta$-carotene group were significantly higher than those of the control group after $7(P<0 \cdot 05), 14(P<0 \cdot 001)$ and $21(P<0 \cdot 001) \mathrm{d}$ of treatment (Fig. 3), and those in the ileum of the $\beta$-carotene group were significantly higher than those of the control group after $14(P<0.001)$ and $21(P<0.05) \mathrm{d}$ of treatment. The numbers of IgA ASC in the jejunum and ileum of mice increased $(P<0.001)$ with age.

\section{Expression of mRNA in tissues}

The mRNA expression of $\operatorname{Ig} A$ C-region in the jejunum of the $\beta$-carotene group was significantly higher $(P<0 \cdot 01)$ than that of the control group after 14 and $21 \mathrm{~d}$ of treatment, and the mRNA expression of CCL25 in the jejunum of the $\beta$-carotene group after $14(P<0.01)$ and $21(P<0.05) \mathrm{d}$ of treatment was significantly higher than that of the control group (Table 1 ). The mRNA expression of $R X R \alpha$ in the jejunum and ileum of the $\beta$-carotene group was significantly higher $(P<0 \cdot 01)$ than that of the control group after $21 \mathrm{~d}$ of treatment. The mRNA expression of $R A R \alpha$ in the jejunum of the $\beta$-carotene group after $21 \mathrm{~d}$ of treatment was significantly higher $(P<0.05)$ than that of the control group, but that of $R A R \alpha$ in the jejunum of the $\beta$-carotene group after $7 \mathrm{~d}$ of treatment was significantly lower $(P<0 \cdot 01)$. The mRNA expression of $R A R \gamma$ in the jejunum of the $\beta$-carotene group after 14 and $21 \mathrm{~d}$ of treatment was significantly higher $(P<0.05)$ than that of the control group, and that of $R A R \gamma$ in the ileum of the $\beta$-carotene group after $21 \mathrm{~d}$ of treatment was significantly higher $(P<0.05)$. There were no significant differences in the mRNA expressions of IgA C-region, CCL25 and RAR $\alpha$ in the ileum between the groups.

\section{Discussion}

IgA antibodies in the intestines are specific to antigens of the intestinal microflora and act to limit the penetration of commensal intestinal bacteria through the neonatal intestinal epithelium $^{(26)}$. After weaning, the intestinal mucosa of mice is exposed to a wide variety of exogenous antigens due to the sudden change in diet and the numbers of Ig-secreting cells are likely to increase ${ }^{(14)}$. Mean faecal IgA concentration of mice at weaning is $3 \cdot 1 \mu \mathrm{g} / \mathrm{g}$, but faecal IgA concentration increases rapidly until $35 \mathrm{~d}$ of age and thereafter remains almost constant ${ }^{(27)}$. In the present study, however, the concentrations of IgA and the numbers of IgA ASC in the jejunum and ileum of weanling mice increased rapidly with age, although concentrations in the faeces and serum increased after $14 \mathrm{~d}$ of treatment and then remained constant.

Supplementation of vitamin A and carotenoids affects the immune cell function during ontogenesis ${ }^{(28)}$, and vitamin A-depleted mice exhibit impaired IgA secretion in mucosal tissues of the small bowel ${ }^{(17)}$. In the present study, supplemental $\beta$-carotene at $50 \mathrm{mg} / \mathrm{kg}$ in the diet increased the concentrations of IgA, the numbers of IgA ASC and the mRNA expression of $\operatorname{Ig} A$ C-region in the jejunum of weanling mice after 14 and $21 \mathrm{~d}$ of treatment, but in the ileum, supplemental $\beta$-carotene only increased the numbers of IgA ASC. On the other hand, supplementation of $\beta$-carotene at $50 \mathrm{mg} / \mathrm{kg}$ in the diet given to maternal mice during pregnancy and lactation enhanced IgA transfer from maternal milk to neonates, owing to the increase in the numbers of IgA ASC in the mammary glands and ileum of maternal mice, but $\beta$-carotene supplementation had no effect on the numbers of IgA ASC and the mRNA expression of $\operatorname{Ig} A$ C-region in the jejunum ${ }^{(12)}$. In the previous ${ }^{(12,13)}$ and present studies, however, $\beta$-carotene supplementation had no effect on IgA concentrations in the serum and faeces of neonatal and weanling mice. Thus, $\beta$-carotene supplementation in weanling mice is effective to enhance mucosal IgA induction in the small intestine, owing to the increase in the numbers of IgA ASC in the jejunum and ileum, but supplemental $\beta$-carotene at $50 \mathrm{mg} / \mathrm{kg}$ in the diet may have a predominant effect on IgA concentrations in the jejunum of weanling mice.

IgA antibodies in the intestines are mainly secreted as dimers after incorporation of the $\mathrm{J}$ chain and association with polymeric Ig receptor (pIgR), and the transport of IgA antibodies from IgA ASC into the intestines is regulated by 
Table 1. mRNA expressions of IgA C-region, CCL25, retinoid X receptor $(R X R) \alpha$, retinoic acid receptor $(R A R) \alpha$ and $R A R \gamma$ in the jejunum and ileum of the control group after $7(n 8), 14(n 8)$ and $21(n 6) \mathrm{d}$ of treatment and the $\beta$-carotene group after $7(n 8)$ $14(n 8)$ and $21(n 6)$ d of treatment*

(Mean values with their standard errors)

\begin{tabular}{|c|c|c|c|c|c|c|}
\hline & \multirow[b]{2}{*}{ Days } & \multicolumn{2}{|c|}{ Control } & \multicolumn{2}{|c|}{$\beta$-Carotene } & \multirow[b]{2}{*}{$P$} \\
\hline & & Mean & SE & Mean & SE & \\
\hline \multicolumn{7}{|l|}{ Jejunum } \\
\hline \multirow[t]{3}{*}{$\lg A \mathrm{mRNA} / G A P D H$} & 7 & 0.79 & 0.13 & 0.87 & 0.12 & 0.660 \\
\hline & 14 & 0.64 & 0.09 & 1.28 & $0 \cdot 15$ & 0.004 \\
\hline & 21 & 1.06 & 0.07 & 1.49 & 0.08 & 0.007 \\
\hline \multirow[t]{3}{*}{ CCL25 mRNA/GAPDH } & 7 & 1.06 & 0.06 & 1.23 & 0.21 & 0.469 \\
\hline & 14 & 0.80 & 0.06 & 1.29 & $0 \cdot 13$ & 0.008 \\
\hline & 21 & 1.00 & 0.04 & 1.35 & $0 \cdot 12$ & 0.029 \\
\hline \multirow[t]{3}{*}{$R X R \alpha$ mRNA/GAPDH } & 7 & 1.00 & 0.14 & $1 \cdot 18$ & $0 \cdot 10$ & 0.343 \\
\hline & 14 & 0.98 & 0.11 & 1.07 & $0 \cdot 13$ & 0.671 \\
\hline & 21 & 0.97 & 0.05 & 1.57 & $0 \cdot 10$ & 0.007 \\
\hline \multirow[t]{3}{*}{$R A R \alpha \mathrm{mRNA} / G A P D H$} & 7 & 1.27 & $0 \cdot 11$ & 0.79 & 0.08 & 0.006 \\
\hline & 14 & 1.00 & 0.07 & 1.13 & $0 \cdot 11$ & 0.379 \\
\hline & 21 & $1 \cdot 10$ & 0.07 & 1.55 & 0.14 & 0.022 \\
\hline \multirow[t]{3}{*}{$R A R \gamma$ mRNA/GAPDH } & 7 & $1 \cdot 20$ & 0.13 & 0.90 & 0.08 & 0.093 \\
\hline & 14 & 0.99 & $0 \cdot 12$ & 1.70 & 0.23 & 0.022 \\
\hline & 21 & 1.00 & 0.07 & 1.68 & $0 \cdot 20$ & 0.014 \\
\hline \multicolumn{7}{|l|}{ Ileum } \\
\hline \multirow[t]{3}{*}{$\lg A \mathrm{mRNA} / G A P D H$} & 7 & 0.71 & 0.07 & 0.62 & 0.06 & 0.430 \\
\hline & 14 & 1.02 & 0.17 & 1.05 & 0.09 & 0.893 \\
\hline & 21 & 1.34 & 0.42 & 1.37 & 0.21 & 0.965 \\
\hline \multirow{3}{*}{ CCL25 mRNA/GAPDH } & 7 & 1.00 & 0.06 & 0.99 & $0 \cdot 16$ & 0.941 \\
\hline & 14 & 1.26 & 0.18 & 1.48 & 0.22 & 0.482 \\
\hline & 21 & $1 \cdot 18$ & 0.32 & 1.27 & 0.21 & 0.836 \\
\hline \multirow[t]{3}{*}{$R X R \alpha$ mRNA/GAPDH } & 7 & 1.04 & 0.05 & 1.12 & 0.09 & 0.497 \\
\hline & 14 & $1 \cdot 12$ & 0.09 & 1.29 & 0.13 & 0.314 \\
\hline & 21 & 0.79 & 0.10 & 1.32 & 0.10 & 0.005 \\
\hline \multirow[t]{3}{*}{$R A R \alpha \mathrm{mRNA} / G A P D H$} & 7 & 1.04 & 0.07 & 0.98 & 0.05 & 0.580 \\
\hline & 14 & 1.41 & 0.11 & 1.09 & 0.11 & 0.065 \\
\hline & 21 & 1.00 & 0.04 & $1 \cdot 16$ & 0.05 & 0.055 \\
\hline \multirow[t]{3}{*}{$R A R \gamma \mathrm{mRNA} / G A P D H$} & 7 & $1 \cdot 13$ & 0.08 & 1.27 & 0.14 & 0.443 \\
\hline & 14 & 1.37 & 0.11 & 1.15 & 0.09 & 0.170 \\
\hline & 21 & 1.30 & 0.07 & 1.61 & 0.08 & 0.026 \\
\hline
\end{tabular}

GAPDH, glyceraldehyde-3-phosphate dehydrogenase.

* mRNA expression is represented relative to IgA C-region, CCL25, RXR $\alpha, R A R \alpha$ and $R A R \gamma$ mRNA expression normalised by the abundance of GAPDH mRNA.

$\operatorname{pIgR}^{(1,4)}$. In the murine small intestine, mature isolated lymphoid follicles are inductive sites for the immune response and nodular lymphoid structures can be observed in the distal small intestine ${ }^{(29)}$. On the other hand, supplementation of fructo-oligosaccharides in mice after weaning was more effective for enhancing IgA levels in the jejunum rather than in the ileum and colon, and supplemental fructo-oligosaccharides increased not only the concentrations of IgA but also the expression of pIgR in the ileum and colon ${ }^{(30)}$. Additionally, coumestrol administration in maternal mice during pregnancy and lactation increased the number of IgA ASC in mammary glands, but had no effect on the concentrations of milk IgA and the mRNA expression of $p I g R$ in mammary glands ${ }^{(31)}$. These results indicate that the increased concentrations of IgA in the jejunum of weanling mice may be due to the increase in the mRNA expression of $\operatorname{IgA} \mathrm{C}$-region and the expression of pIgR caused by $\beta$-carotene supplementation.

Gut-associated lymphoid tissue dendritic cells rely on RA to induce IgA class switching, and RA is essential for the imprinting of gut-homing receptors on $\mathrm{T}$ and $\mathrm{B}$ cells and contributes to IgA production ${ }^{(16,17)}$. CCL25 plays essential roles in intestinal homing of IgA ASC primarily by mediating their extravasation into intestinal lamina propria $^{(18)}$. RA is important for the induction of the expression of CCR9 on activated $\mathrm{T}$ cells, and the blocking of RA receptors decreases the induction of gut-homing receptors ${ }^{(16)}$. In the present study, supplemental $\beta$-carotene increased the mRNA expressions of CCL25 and RAR $\gamma$ in the jejunum after 14 and $21 \mathrm{~d}$ of treatment and those of $R X R \alpha$ and $R A R \alpha$ in the jejunum and of $R X R \alpha$ and $R A R \gamma$ in the ileum after $21 \mathrm{~d}$ of treatment, although it decreased the mRNA expression of $R A R \alpha$ in the jejunum after $7 \mathrm{~d}$ of treatment. These results imply that the enhanced mucosal IgA induction caused by $\beta$-carotene supplementation is mainly due to the RA-mediated immune response, owing to the increased mRNA expressions of $R X R \alpha, R A R \alpha$ and $R A R \gamma$ in the jejunum and of $R X R \alpha$ and $R A R \gamma$ in the ileum, and $\beta$-carotene supplementation may influence the expression of chemokine receptor CCR9 on developing IgA ASC in the jejunum.

In conclusion, the present study suggests that supplementation of $\beta$-carotene in mice after weaning is useful for 
enhancing mucosal IgA induction in the intestines, owing to the increase in the concentrations of $\operatorname{IgA}$, the numbers of IgA ASC and the mRNA expression of $\operatorname{IgA} \mathrm{C}$-region in the jejunum and the numbers of IgA ASC in the ileum. Foods containing animal products and pro-vitamin A carotenoids are the primary source of vitamin A, but vitamin A deficiency is associated with an increased risk of death from common childhood infections ${ }^{(3,10)}$. Supplementation of $\beta$-carotene-enriched formulas may improve the immune system of neonates, because $\beta$-carotene has not been detected in four of eight brands of formula preparations and plasma $\beta$-carotene of formula-fed children is significantly lower than that of breast milk-fed children ${ }^{(6)}$. However, for children aged $1-3$ years in the USA, the median vitamin A intake from foods and supplements is $1205 \mu \mathrm{g}$ of retinol activity equivalent/d and exceeds the tolerable upper level of $600 \mu \mathrm{g} / \mathrm{d}$, but does not exceed the no-observed-adverse-effect level of $6000 \mu \mathrm{g} / \mathrm{d}^{(32)}$. Further study is needed to clarify the optimal and toxic levels of $\beta$-carotene in formulas to improve the immune system of neonates.

\section{Acknowledgements}

The present study did not receive any financial support. Experimental $\beta$-carotene was kindly provided by Sceti Company Limited (Tokyo, Japan).

The contributions of the authors are as follows: K. N., M. S., S. I. and S. K. designed the research; K. N. conducted most of the research; K. N. and S. K. contributed equally to the discussion and to the writing of the manuscript.

The authors have no conflicts of interest to declare.

\section{References}

1. Fagarasan S \& Honjo T (2003) Intestinal IgA synthesis: regulation of front-line body defences. Nature Immunol $\mathbf{3}$, 63-72.

2. Sigmundsdottir H \& Butcher EC (2008) Environmental cues, dendritic cells and the programming of tissue-selective lymphocyte trafficking. Nature Immunol 9, 981-987.

3. Ertesvåg A, Naderi S \& Blomhoff HK (2009) Regulation of B cell proliferation and differentiation by retinoic acid. Semin Immunol 21, 36-41.

4. Wheeler TT, Hodgkinson AJ, Prosser CG, et al. (2007) Immune components of colostrum and milk - a historical perspective. J Mammary Gland Biol Neoplasis 12, 237-247.

5. Bendich A \& Shapiro SS (1986) Effect of $\beta$-carotene and canthaxanthin on the immune responses of the rat. $J$ Nutr 116, 2254-2262.

6. Sommerburg O, Meissner K, Nelle M, et al. (2000) Carotenoid supply in breast-fed and formula-fed neonates. Eur $J$ Pediatr 159, 86-90.

7. Rühl R (2007) Effects of dietary retinoids and carotenoids on immune development. Proc Nutr Soc 66, 458-469.

8. Chew BP \& Park JS (2004) Carotenoid action on the immune response. J Nutr 134, 257S-261S.

9. Kume $S \&$ Toharmat $T$ (2001) Effect of colostral $\beta$-carotene and vitamin $A$ on vitamin and health status of newborn calves. Livest Prod Sci 68, 61-65.
10. Mora JR \& von Andrian UH (2009) Role of retinoic acid in the imprinting of gut-homing IgA-secreting cells. Semin Immunol 21, 28-35.

11. Stephensen CB, Moldoveanu Z \& Gangopadhyay NN (1996) Vitamin A deficiency diminishes the salivary immunoglobulin A response and enhances the serum immunoglobulin $G$ response to influenza $\mathrm{A}$ virus infection in BALB/c mice. J Nutr 126, 94-102.

12. Nishiyama Y, Sugimoto M, Ikeda S, et al. (2011) Supplemental $\beta$-carotene increases IgA-secreting cells in mammary gland and IgA transfer from milk to neonatal mice. $\mathrm{Br} J$ Nutr 105, 24-30.

13. Nishiyama Y, Yasumatsuya K, Kasai K, et al. (2011) Effects of supplemental $\beta$-carotene with whey on IgA transfer from maternal milk and mucosal IgA induction in neonatal mice and calves. Livest Sci 137, 95-100.

14. Van del Heijden PJ, Bianchi ATJ, Stok W, et al. (1988) Background (spontaneous) immunoglobulin production in the murine small intestine as a function of age. Immunology 65, 243-248.

15. Morteau O, Gerard G, Lu O, et al. (2008) An indispensable role for the chemokine receptor CCR10 in IgA antibody-secreting cell accumulation. J Immunol 181, 6309-6315.

16. Iwata M, Hirakiyama A, Eshima Y, et al. (2004) Retinoic acid imprints gut-homing specificity on $\mathrm{T}$ cells. Immunity $\mathbf{2 1}$, $527-538$.

17. Mora JR, Iwata M, Eksteen B, et al. (2006) Generation of guthoming IgA-secreting B cells by intestinal dendritic cells. Science 314, 1157-1160.

18. Hieshima K, Kawasaki Y, Hanamoto H, et al. (2004) CC chemokine ligands 25 and 28 play essential roles in intestinal extravasation of IgA antibody-secreting cells. J Immunol 173, 3668-3675.

19. Wurbel M, Phillipe J, Nguyen C, et al. (2000) The chemokine TECK is expressed by thymic and intestinal epithelial cells and attracts double- and single-positive thymocytes expressing the TECK receptor CCR9. Eur J Immunol 30, 262-271.

20. Papadakis KA, Prehn J, Nelson V, et al. (2000) The role of thymus-expressed chemokine and its receptor CCR9 on lymphocytes in the regional specialization of the mucosal immune system. J Immunol 165, 5069-5076.

21. Haq R, Pfahl M \& Chytil F (1991) Retinoic acid affects the expression of nuclear retinoic acid receptors in tissues of retinol-deficient rats. Proc Natl Acad Sci U S A 88, 8272-8276.

22. Takase S, Suruga S \& Goda T (2000) Regulation of vitamin A metabolism-related gene expression. Br J Nutr 84, Suppl. 2, S217-S221.

23. Szondy S, Reichert U \& Fesüs L (1998) Retinoic acids regulate apoptosis of $\mathrm{T}$ lymphocytes through an interplay between RAR and RXR receptors. Cell Death Differ 5, 4-10.

24. Lømo J, Smeland EB, Ulven S, et al. (1998) RAR-, not RXR, ligands inhibit cell activation and prevent apoptosis in B-lymphocytes. J Cell Physiol 175, 68-77.

25. Statistical Analysis Systems (SAS) (1997) SAS/STAT Software: Changes and Enhancement Through Release 6.12. Cary, NC: SAS Institute.

26. Harris NL, Spoerri I, Schopfer JF, et al. (2006) Mechanisms of neonatal mucosal antibody protection. J Immunol 177, 6256-6262.

27. Takagi N, Hasegawa S, Sugimoto M, et al. (2010) Effects of feeding whey protein or skim milk protein on nitrogen utilization and fecal IgA in mice after weaning. Kansai J Anim Sci (In Japanese, with English abstract) 166, 1-9. 
28. Garcia AL, Rühl R, Herz U, et al. (2003) Retinoid- and carotenoid-enriched diets influence the ontogenesis of the immune system in mice. Immunology 110, 180-187.

29. Lorenz RG, Chaplin DD, McDonald KG, et al. (2003) Isolated lymphoid follicle formation is inducible and dependent upon lymphotoxin-sufficient B lymphocytes, lymphotoxin beta receptor, and TNF receptor I function. J Immunol 170, 5475-5482.

30. Nakamura Y, Nosaka S, Suzuki M, et al. (2004) Dietary fructooligosaccharides up-regulate immunoglobulin A response and polymeric immunoglobulin receptor expression in intestinal of infant mice. Clin Exp Immunol 137, 52-58.

31. Wang M, Sugimoto M, Ikeda S, et al. (2013) Effects of coumestrol administration to maternal mice during pregnancy and lactation on IgA-secreting cells in mammary gland. Anim Sci J 84, 322-327.

32. Allen LH \& Haskell M (2002) Estimating the potential for vitamin A toxicity in women and young children. $J$ Nutr 132, 2907S-2919S. 